Published in "Phytochemistry 112: 54-62, 2015"

which should be cited to refer to this work.

\title{
Reactive oxygen species and plant resistance to fungal pathogens
}

\author{
Silke Lehmann ${ }^{\mathrm{a}, 1}$, Mario Serrano ${ }^{\mathrm{a}, 1}$, Floriane L'Haridon ${ }^{\mathrm{a}, 1}$, Sotirios E. Tjamos ${ }^{\mathrm{b}, 1}$, Jean-Pierre Metraux ${ }^{\mathrm{a}, *}$ \\ a Department of Biology, University of Fribourg, 10 chemin du Musée, CH-1700 Fribourg, Switzerland \\ ${ }^{\mathrm{b}}$ Laboratory of Plant Pathology, Department of Crop Science, Agricultural University of Athens, 75 Iera Odos, 11855 Athens, Greece
}

\begin{abstract}
Reactive oxygen species (ROS) have been studied for their role in plant development as well as in plant immunity. ROS were consistently observed to accumulate in the plant after the perception of pathogens and microbes and over the years, ROS were postulated to be an integral part of the defence response of the plant. In this article we will focus on recent findings about ROS involved in the interaction of plants with pathogenic fungi. We will describe the ways to detect ROS, their modes of action and their importance in relation to resistance to fungal pathogens. In addition we include some results from works focussing on the fungal interactor and from studies investigating roots during pathogen attack.
\end{abstract}

\section{Introduction}

So-called reactive oxygen species (ROS) include various forms of reduced and chemically reactive molecules such as superoxide anion $\left(\mathrm{O}_{2} \cdot\right)$, hydrogen peroxide $\left(\mathrm{H}_{2} \mathrm{O}_{2}\right)$, hydroxyl radical $(\mathrm{OH}$.$) or$ hydroperoxyl radical $\left(\mathrm{HO}_{2}\right.$. $)$. Up to the 1980 s the synthesis as well as the detoxification of ROS had already attracted many researchers and ROS were much studied for their role in plant

* Corresponding author. Tel.: +41 26300 8811; fax: +41263009740.

E-mail addresses: silke.lehmann@unifr.ch (S. Lehmann), marioalberto. serranoortega@unifr.ch (M. Serrano), floriane.Iharidon@unifr.ch (F. L'Haridon), sotiris@aua.gr (S.E. Tjamos), jean-pierre.metraux@unifr.ch (J.-P. Metraux).

1 These authors contributed equally to this work. development (Elstner, 1982; Swanson and Gilroy, 2010; Tian et al., 2013).

In 1983, Doke reported a production of $\mathrm{O}_{2}$. during an incompatible interaction of potato with the oomycete Phytophthora infestans (Doke, 1983). This observation set forth a considerable wave of studies on the production of ROS in whole plants or in suspension cells confronted with live pathogens or various elicitors. It has become apparent that ROS are an integral response to both biotic and abiotic stress. A large number of reviews have been dedicated to this topic (Apel and Hirt, 2004; Baker and Orlandi, 1995; Barna et al., 2012; Baxter et al., 2013; Foyer and Noctor, 2013; Laloi et al., 2004; Mehdy, 1994; Miller et al., 2008; Mittler, 2002; Mittler et al., 2011; O'Brien et al., 2012a; Sutherland, 1991). In this article, we 
will briefly review the available methods to detect the formation of ROS in plant tissue. We will then discuss the different possible modes of action of ROS, as their deployment is among the early reactions after the perception of pathogen-, microbe- or damageassociated molecular patterns (PAMPs, MAMPs or DAMPs) by pattern recognition receptors (Boller and Felix, 2009; Torres, 2010; Torres et al., 2006). Finally, we will review the more recent evidence establishing the link between ROS production and resistance to fungal pathogens both in leaves and the roots.

\section{Detection of ROS}

Many methods are used to detect the accumulation of ROS. They are based on histochemical staining, fluorescence, luminescence, electron paramagnetic resonance (EPR) spectroscopy or ROS sensors (Table 1). Fluorescent probes, $\mathrm{CeCl}_{3}$ and ROS sensors are also used for a subcellular localisation of ROS. A difficulty with the detection of ROS lies in their relative short life-times combined with the ability of living cells to scavenge ROS. Furthermore, tissue damage or disruption during tissue handling might generate ROS artefacts. The lack of probes with a high selectivity is another hurdle. In other words, no probe is guaranteed to work for a given tissue under given conditions. Given these difficulties, researchers engaging in the detection and localisation of ROS in plant tissue are therefore advised to make the necessary controls and preliminary tests to determine the validity of the probes they are using. This includes using more than one method to support their conclusions. In the next section, we have briefly summarised the most common approaches used and indicated some recent publications where they have been applied. The reader is referred to several useful reviews on methodological aspects and associated difficulties and limitations concerning ROS detection (Freinbichler et al., 2011; Nauseef, 2014; Winterbourn, 2014; Zulfugarov et al., 2011).

$\mathrm{H}_{2} \mathrm{O}_{2}$ can be detected with the histochemical stain 3-3' diaminobenzidine (DAB) that forms instantly a brownish polymer in presence of $\mathrm{H}_{2} \mathrm{O}_{2}$ and peroxidase (Thordal-Christensen et al., 1997). DAB staining has been often used to visualise the generation of $\mathrm{H}_{2} \mathrm{O}_{2}$ in planta (Asai et al., 2010; Dubreuil-Maurizi et al., 2010; Kobayashi et al., 2012; L'Haridon et al., 2011; Liao et al., 2012; Rojas et al., 2012; Simon et al., 2013; Torres et al., 2005; Yokawa et al., 2011; Zhang et al., 2012). The Amplex Red hydrogen peroxide/peroxidase activity assay also allows quantifying $\mathrm{H}_{2} \mathrm{O}_{2}$ concentrations and consists in a non-fluorescent molecule that is oxidised by $\mathrm{H}_{2} \mathrm{O}_{2}$ and becomes fluorescent in presence of peroxidase. Recent examples of this method applied to plants are cited hereafter (Shin and Schachtman, 2004; Zhang et al., 2012). An analogous method to quantify $\mathrm{H}_{2} \mathrm{O}_{2}$ uses 3-methylbenzothiazoline hydrazine that reacts in presence of peroxidases (Malolepsza and Rozalska, 2005). Assays with ferrous ion oxidation (FOX) are based on the spectrophotometrical detection of peroxide-mediated oxidation of $\mathrm{Fe}^{2+}$ to $\mathrm{Fe}^{3+}$ ions that forms a complex with xylenol orange. The FOX method was used on cultured suspension cells (Boubakri et al., 2013; O'Brien et al., 2012b) or on incubation medium of leaf explants (Bellincampi et al., 2000). Other methods to determine $\mathrm{H}_{2} \mathrm{O}_{2}$ spectrophotometrically in plant samples include the use of resorcinol/titanium oxalate (Becana et al., 1986) or ABTS (2,2'-Azino-bis-(3-ethylbenthiazoline-6-sulfonate)) (formation of blue colour) (Messner and Boll, 1994). The cytochemical staining using cerium (III) chloride $\left(\mathrm{CeCl}_{3}\right)$ is used for a subcellular localisation of $\mathrm{H}_{2} \mathrm{O}_{2}$. The reaction between $\mathrm{CeCl}_{3}$ and an excess of $\mathrm{H}_{2} \mathrm{O}_{2}$ generates electron-dense deposits of cerium perhydroxides that can be observed using transmission electron microscopy (Bestwick et al., 1998; Fester and Hause, 2005; Lherminier et al., 2009; Simon et al., 2013; Xia et al., 2009).

To visualise superoxide oxygen anions in the plant tissue, the histochemical stain nitroblue tetrazolium (NBT) is frequently used.
Table 1

Summary of different techniques that are used to detect ROS in plants.

\begin{tabular}{lll}
\hline Product & $\begin{array}{l}\text { Reactive } \\
\text { oxygen } \\
\text { species }\end{array}$ & Detection \\
\hline 3-3' diaminobenzidine (DAB) & $\mathrm{H}_{2} \mathrm{O}_{2}$ & Histochemical \\
Amplex red & $\mathrm{H}_{2} \mathrm{O}_{2}$ & Spectrophotometrical \\
3-Methylbenzothiazoline hydrazine & $\mathrm{H}_{2} \mathrm{O}_{2}$ & Spectrophotometrical \\
Ferrous ion oxidation (FOX) & $\mathrm{H}_{2} \mathrm{O}_{2}$ & Spectrophotometrical \\
$\mathrm{Ti}^{4+}$ method & $\mathrm{H}_{2} \mathrm{O}_{2}$ & Spectrophotometrical \\
ABTS & $\mathrm{H}_{2} \mathrm{O}_{2}$ & Spectrophotometrical \\
Cerium (III) chloride (CeCl $\left.{ }_{3}\right)$ & $\mathrm{H}_{2} \mathrm{O}_{2}$ & Cytochemical \\
Nitroblue tetrazolium (NBT) & $\mathrm{O}_{2} \cdot$ & Histochemical \\
Dihydroethidium (DHE) & $\mathrm{O}_{2} \cdot{ }^{-}$ & Fluorescence \\
2-Deoxyribose (DOR) & $\mathrm{OH}^{\cdot}$ & Spectrophotometrical \\
Spin trapping electron paramagnetic & $\mathrm{Oxygen} \mathrm{free}$ & Spectroscopy \\
$\quad$ resonance spectroscopy (EPR) & $\mathrm{radicals}$ & \\
Dansyl-based fluorescence sensors & $\mathrm{O}_{2 \cdot} \cdot{ }^{1} \mathrm{O}_{2}$ & Fluorescence \\
Singlet Oxygen Sensors Green (SOGS) & ${ }^{1} \mathrm{O}_{2}$ & Fluorescence \\
Fluorescein diacetate & $\mathrm{ROS}$ & Fluorescence \\
Dihydrorhodamine123 & $\mathrm{ROS}$ & Fluorescence \\
Luminol & $\mathrm{ROS}$ & Chemiluminescence \\
\hline
\end{tabular}

Yellow, water-soluble NBT is reduced by superoxide radicals to blue, water-insoluble formazan (Grosskinsky et al., 2012; Jabs et al., 1996; Kawarazaki et al., 2013; L'Haridon et al., 2011; Liao et al., 2012; Wang and Higgins, 2006; Xia et al., 2009). Superoxide anion radicals can also be detected using dihydroethidium (DHE), a cell-permeable blue fluorescent stain that forms red fluorescent oxyethidium upon oxidation and intercalates with nucleic acids (see recent applications in Lehotai et al., 2011; Mai et al., 2013; Petö et al., 2013). The hydroxyl radicals can be quantified using 2-deoxyribose (DOR), a scavenger and a probe as exemplified in the study on Botrytis cinerea-infected tomato leaves by Malolepsza and Rozalska, 2005. DOR is sensitive to hydroxyl radicals and thiobarbituric acid-reactive degradation products are formed that can be determined spectrophotometrically (von Tiedemann, 1997). Electron paramagnetic resonance spin trapping spectroscopy (EPR) allows detection of oxygen free radicals or other species with unpaired electrons (reviewed by Bacic and Mojovic, 2005). Diamagnetic spin traps are used that react with free radicals and form an adduct that can be detected using EPR spectroscopy. For example, this method was used to detect the singlet oxygen in thylakoid membranes under photoinhibitory conditions or UV stress (Hideg et al., 1994, 1995). The singlet oxygen and superoxide anion radicals can be also detected and localised using dansyl-based fluorescence sensors such as DanePy or HO-1889-NH (Hideg et al., 2002) as well as a Singlet Oxygen Sensors Green (SOGS) (Flors et al., 2006; Plancot et al., 2013).

Fluorescein diacetate $\left(\mathrm{H}_{2}\right.$ DCF-DA, CM- $\mathrm{H}_{2}$ DCF-DA) and dihydrorhodamine 123 are among the commonly used fluorescent probes to detect a broad spectrum of ROS. They consist in non-fluorescent molecules that become fluorescent when oxidised by ROS, and the emitted fluorescence can be observed by fluorimetry and/or by fluorescent microscopy, an advantage of such probes (Benikhlef et al., 2013; Bulgakov et al., 2012; Fester and Hause, 2005; Guo et al., 2010; Kolla et al., 2007; L'Haridon et al., 2011; Li et al., 2007; Liu et al., 2010; Ma et al., 2013; Peleg-Grossman et al., 2012; Plancot et al., 2013; Tada et al., 2004; Wen et al., 2008; Ye et al., 2013). Luminol or luminol analogues are sensitive chemiluminescent probes used to quantify a relative intensity of ROS by counting the emitted light with a luminometer, CDD camera or a scintillation counter (Dubreuil-Maurizi et al., 2010; Flury et al., 2013; Kunz et al., 2006; L'Haridon et al., 2011; Mersmann et al., 2010). Finally, it is possible to determine the redox potential of the glutathione pool in a high spatial and temporal resolution using various redox-sensitive green fluorescent proteins (for example roGFP) encoded in the test plant. The method requires transient 
or permanent plant transformation and has already been used in many cases (Beneloujaephajri et al., 2013; Heller et al., 2012; Jubany-Mari et al., 2010; Lehmann et al., 2009; Rosenwasser et al., 2011).

\section{The multiple functions of ROS}

ROS released in plants during an interaction with microbes can affect both partners. Fungal pathogens as well as other invading microorganisms are exposed to the oxidative stress generated by ROS and they have evolved multiple ways to scavenge ROS using for example small molecules (glutathione, ascorbic acid, flavonoids, alkaloids and carotenoids) that will be oxidised by ROS, as well as detoxifying enzymes (superoxide dismutase, peroxidase, catalase, peroxiredoxins)

One approach to evaluate the importance of ROS for plant defences is to interfere with the mechanisms deployed by pathogens that protect them against ROS. Recently, the transcription factor Moatf1 homologous to the yeast ATF/CREB that regulates the oxidative stress response was identified in Magnaporthe grisea. Targeted gene deletion of Moatf results in a higher sensitivity to ROS, a reduced expression and activity of extracellular laccases and peroxidases associated with a reduced virulence on rice (Guo et al., 2010). $\mathrm{H}_{2} \mathrm{O}_{2}$ accumulated around the appressorium in the deletion mutant but not in the wild type fungus and inhibition of the rice NADPH oxidases with diphenyleneiodonium (DPI) restored hyphal growth and virulence of the mutant (Guo et al., 2010). The MoHYR1 gene of M. oryzae encodes a glutathione peroxidase GSHPx domain and was shown to be part of the antioxidative defence in $M$. grisea, since $\Delta$ hyr 1 deletion mutants were impaired in tolerance to $\mathrm{H}_{2} \mathrm{O}_{2}$ in vitro and in planta as well as in virulence (Huang et al., 2011). Confocal imaging using fluorescent reporters was used to characterise the cytosolic glutathione redox potential during spore germination, appressorium formation and infection. Results show

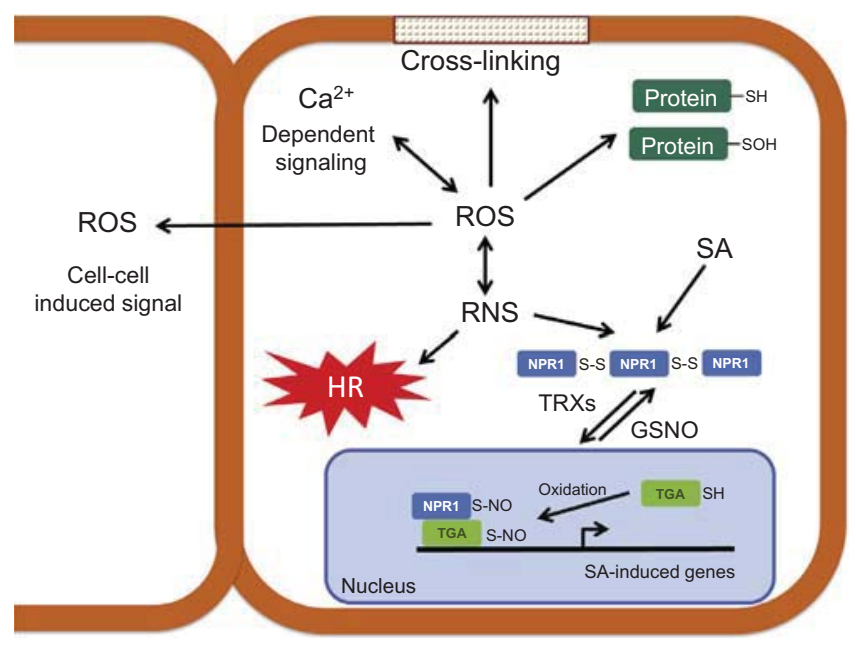

Fig. 1. The multifaceted actions of ROS. The most important ROS-induced mechanisms during plant-microbe interactions are shown. Peroxidase- and ROS-induced cross-linking of cell wall components is part of the defence mechanisms not only against microbes but also insects. ROS can modify multiple biological processes by active post-translational modification (PTM) that includes sulfenylation of cysteine residues $(\mathrm{SOH})$. A well-characterised pathogen-triggered PTM that is dependent on ROS and reactive nitrogen species (RNS), is the reduction and resulting interaction of the SA-induced protein NPR1 and TGA transcription factors. The equilibrium of this induction is regulated by the action of the enzymes S-nitrosoglutathione (GSNO) and thioredoxins (TRXs). Additionally, a defence-induced programmed cell death (PCD), named hypersensitive response (HR) is induced and regulated by the complex crosstalk between ROS and RNS. Finally, ROS can modify other multiple signalling pathways and cell to cell responses induced by different biotic and abiotic stimuli, by the oxidation-dependent regulation of transcription factors and by the co-regulation and co-induction of the secondary messenger $\mathrm{Ca}^{2+}$. that $M$. grisea is endowed with solid antioxidative defences even during reduced penetration of the fungus in resistant hosts and ROS produced by the host are unlikely to be a direct toxic barrier for the fungus (Samalova et al., 2014). YAP-1 of Ustilago maydis is a homolog of the yeast AP-1-like protein that regulates the response to oxidative stress. Deletion mutants of $U$. maydis lacking a functional YAP-1 gene exhibit a decreased virulence. This is associated with an increase in $\mathrm{H}_{2} \mathrm{O}_{2}$ detected at the hyphal tips of the penetrating deletion mutant. No accumulation of $\mathrm{H}_{2} \mathrm{O}_{2}$ was observed around the tips of penetrating hyphae of the wild type fungus. Treating the host plant with DPI restores the virulence of the deletion mutant (Molina and Kahmann, 2007). These studies exemplify how detoxification of host-derived ROS is essential for fungal virulence and pathogenesis.

But ROS can also be sensed by fungal pathogens and act as developmental signals for the differentiation of infection structures (Heller and Tudzynski, 2011). Recent studies succeeded in monitoring the intracellular redox status in $B$. cinerea by expressing a redox-sensitive green fluorescent protein (roGFP) as a biosensor for the redox status in the fungus. This elegant approach showed the importance of intracellular redox differences between infecting hyphae or in appressorial structures during fungal invasion (Heller et al., 2012). Similar observations were made in M. grisea lines where glutathione and ROS production where determined by live cell imaging using Grx1-roGFP2 and fluorescent markers (Samalova et al., 2014).

Rather than direct antimicrobial molecules, ROS are more likely cofactors in redox reactions playing various roles in plant defences (Torres, 2010). For instance, ROS have been characterised as primary signalling molecules, regulating multiple physiological processes during plant growth and development (De Tullio, 2010). Interestingly, evolutionary considerations based on the NADPH gene family suggest that mechanisms to detoxify ROS were acquired before the plants used ROS as signalling molecules (Mittler et al., 2011).

The reasons that make ROS important signalling regulators are: (i) fast control over the production and scavenge in individual cells, allowing a dynamic control of ROS levels; (ii) ROS can accumulate in different subcellular organelles, resulting in an efficient intracellular control; (iii) ROS-induced signalling is rapidly propagated from the origin of the stimuli to the rest of the cells; (iv) the chemical nature of ROS allows them to interact and modify different targets (reviewed in Mittler et al., 2011). Remarkably, plants exploit this advantageous versatility of ROS when interacting with the environment and during biotic interactions (Scheler et al., 2013). Here we describe the most relevant roles of ROS during plantpathogen interactions (Fig. 1).

\subsection{Modification of the cell wall}

The reinforcement of the cell wall at the site of interaction with the pathogen is an important pathogen-induced defence response. It is mediated by de novo pathogenesis-related (PR) protein synthesis including the class III plant peroxidases. Peroxidases mediate ROS-dependent cross-linking of components of the cell wall including glycoproteins, lignin and suberin (Almagro et al., 2009). ROS-mediated cell wall modifications are also involved in the defence of plants against insects. Cell wall modifications mediated by ROS also take part during the interaction of wheat (Triticum aestivum) or rice (Oryza sativa) with larvae of the Hessian fly (Mayetiola destructor) (Liu et al., 2010).

\subsection{Signal transduction pathways}

ROS regulate different plant hormone signalling pathways, plant-biotic interactions and developmental processes by redox- 
dependent regulation of transcription factors (Barna et al., 2012). There is evidence that indicates the direct induction of defence responses mediated by ROS (Torres, 2010). However, under several biotic and abiotic stress conditions the secondary messenger $\mathrm{Ca}^{2+}$ is also induced besides ROS accumulation. Since ROS and $\mathrm{Ca}^{2+}$ are co-produced and co-regulate each other, the analysis of the regulation of these pathways is complex (Wrzaczek et al., 2013). One of the best characterised defence signalling pathways regulated by oxidation events is the induction of salicylic acid (SA)-dependent responses and attending regulation of two key regulators: the SA receptor NPR1 and TGA transcription factors in Arabidopsis thaliana (Liao et al., 2012; Fu and Dong, 2013). Briefly, under non-stress conditions NPR1 is S-nitrosylated at the cysteine-156 by S-nitrosoglutathione (GSNO) and sequestered in the cytoplasm as an oligomer formed by disulphide bounds. Once SA accumulates upon pathogen attack and alters the cellular redox state, this provokes a reduction of the disulphide bonds in the NPR1 protein by the thioredoxins TRX-h3 and TRX-h5 (Tada et al., 2008). Even further, a change in the oxidation state of cysteine residues of TGA transcription factors has been shown to be necessary to promote their interaction with NPR1 in the nucleus (Després et al., 2003). The reduced form of the NPR1 oligomer releases NPR1 monomers that translocate to the nucleus and interact with the oxidised TGA transcription factors, promoting the induction of defence response genes (Tada et al., 2008). Remarkably, ROS accumulation does not always result in an induction of SA-dependent defence responses. During symbiotic interactions in legume roots, ROS production is stronger and lasts longer than during plant-pathogen interactions, but in this case, the expression of PR proteins is reduced (PelegGrossman et al., 2012), highlighting the complexity of the ROSdependent signal transduction.

\subsection{Programmed cell death}

The programmed cell death (PCD) is an essential mechanism during the growth and development of several organisms including plants. PCD is a highly genetically controlled and orchestrated process that leads to the degradation of proteins, lipids and DNA, destruction of the plasma membrane and phosphatidylserine externalisation, that ends with the destruction of the cell (Dickman and de Figueiredo, 2013). During the last years, PCD in plants has been extensively characterised and several molecular players have been recently described, including the endoplasmic reticulum (ER), $\mathrm{Ca}^{2+}$, nitric oxide (NO) and ROS (reviewed in Agurla et al., in press; Garcion et al., 2014; van Doorn et al., 2011; Williams et al., 2014). In plants, PCD takes place during leaf senescence, photosynthesis and as part of the innate immune response triggered by plant-pathogen interactions, called hypersensitive response (HR). ROS-induced PCD has been described as a mechanism of photooxidative damage during photosynthesis, since plants under severe light stress show PCD induced by an increase in the level and toxicity of singlet oxygen ${ }^{1} \mathrm{O}_{2}$ (Triantaphylides et al., 2008). Interestingly, a recent analysis indicates that under non-stress light conditions ${ }^{1} \mathrm{O}_{2}$ can also play a role as signalling molecule, regulating the PCD pathway and generating microscopic lesions in the leaf (Kim et al., 2012). Concerning plantpathogen interactions, NO and ROS participate in a coordinated way in regulated HR (Bellin et al., 2012). In agreement with this, recent reports have established that reactive nitrogen species (RNS) and ROS are not only crucial players during HR but actually both participate in a complex crosstalk were they can interact and regulate each other (reviewed in Wang et al., 2013). Nevertheless, depending on the biotic interaction, ROS can interfere with PCD induction and regulation or might not be involved at all (Torres, 2010). This indicates that PCD is under a complex regulation, where ROS have an important role but are not the only player.

\subsection{Post-translational regulation}

ROS have an important role as modulator of different biological processes such as plant-biotic interactions and development, acting on protein post-translational modifications (PTM). ROS can affect PTMs by at least two mechanisms: $\mathrm{H}_{2} \mathrm{O}_{2}$ can modify the cysteine residues producing a sulfenic acid $(-\mathrm{SOH})$ by the chemical reaction called sulfenylation (Scheler et al., 2013) and oxidation of methionine residues within a phosphorylation motif can inhibit phosphorylation of neighbouring peptides (Hardin et al., 2009). During the symbiotic interaction between Medicago truncatula and Sinorhizobium meliloti multiple proteins involved in nitrogen fixation are sulfenylated, highlighting the importance of ROS in the establishment and development of this plant-biotic interaction (Oger et al., 2012). On the other hand, Triticum aestivum seeds germinated in the presence of cadmium and other oxidative stressors showed that ROS-induced PTM of proteins are involved in cell cycle progression during root growth, affecting G1/S transition and progression through the S phase (Pena et al., 2012).

\section{ROS and resistance to fungal pathogens of leaves}

In this part we review some examples illustrating the relevance of ROS in the defence of the plant to various, mostly fungal pathogens. The importance of ROS in the defence of the plant has been tested by various attempts to inhibit their production. An efficient way to block ROS production is difficult to find, since several major sources of ROS exist in plant cells. These include a number of enzyme systems that comprise among others NADPH oxidases, superoxide dismutase, oxalate oxidase, cell wall peroxidases, lipoxygenases and polyamine oxidases (Bolwell, 1999; Shetty et al., 2008; Torres et al., 2013; Yoda et al., 2009; Zimmermann et al., 2006).

NADPH oxidases also termed homologues of mammalian respiratory burst oxidases (RBOHs) are associated with ROS formation during the interaction of plants with pathogens (Suzuki et al., 2011). The cDNAs of 2 RBOHs were described in Nicotiana benthamiana: $N b R B O H A$ expressed constitutively at low levels and $N b R B O H B$ induced by the elicitor INF1 from the oomycete $P$. infestans a pathogen of potato. When these genes were silenced by virus-induced gene silencing the suppressed plants show a reduction in ROS accumulation and INF1-induced cell death, along with a loss in resistance to $P$. infestans (Asai et al., 2008; Yoshioka et al., 2003).

Among the 10 sequences encoding RBOHs in A. thaliana, AtRboh $D$ and $F$ have been identified as crucial for ROS formation in leaves and B and C in seed and root respectively (Marino et al., 2012). A decreased ROS production in response to infection with avirulent Pseudomonas syringae pv tomato DC3000 and Hyaloperonospora parasitica was observed in double mutants of AtRboh $D$ and $F$ (Torres et al., 2002). But rather than generating ROS that act directly in the activation of defences, ROS produced by AtRboh D and $\mathrm{F}$ might limit the spread of cell death around bacterial infection sites (Torres et al., 2005). This was shown by studies with lsd1 (lesion simulating disease 1) mutants that form spontaneous lesions that remain localised; when AtRbohD/F are suppressed in Isd1 mutants as in the triple mutants lsd1/atRbohD/atRbohF, the plants develop spreading lesions. In fact, mutants of RbohD are similarly susceptible to a virulent strain of $P$. syringae whereas mutants of RbohF display a slight increase in susceptibility compared to controls (Chaouch et al., 2012).

In potato a $\mathrm{Ca}^{2+}$-dependent protein kinase (StCDPK5) was found to phosphorylate a plasma membrane $\mathrm{RBOH}$ leading to an oxidative burst. Transgenic potato expressing a constitutively active form of StCDPK5 under a pathogen-inducible promoter allowed 
determining the implication of ROS in the defence of potato to pathogens using a gain-of-function approach. Inoculation of such plants with virulent isolates of $P$. infestans induced ROS and increased resistance to the pathogen. However, transgenic plants were more susceptible to the necrotrophic pathogen Alternaria solani. Thus, RBOH-dependent ROS participate in the defence to hemibiotrophic pathogens, but help the necrotrophic pathogen in the colonisation of the tissue (Kobayashi et al., 2012). In agreement with these data, $N b R b o h B$-silenced $N$. benthamiana plants develop smaller lesions after inoculation with $B$. cinerea (Asai and Yoshioka, 2009). However, Rboh-mediated ROS accumulation is not strictly correlated with disease susceptibility towards $B$. cinerea. The treatment of Arabidopsis leaves with oligogalacturonides (OGs) elicits an AtRbohD-dependent oxidative burst and protects Arabidopsis plants from subsequent attack by $B$. cinerea. Despite the loss of the OG-elicited ROS-burst, atrbohD T-DNA mutants still exhibit an induction of defence genes and an increased resistance towards B. cinerea after OG-treatment (Galletti et al., 2008). A recent study suggests nitric oxide (NO) to act as an upstream regulator of the OG-elicited oxidative burst mediated by AtRbohD (Rasul et al., 2012). A link between disease resistance, NO and ROS was also indicated by analysing different Arabidopsis ecotypes after inoculation with Sclerotinia sclerotiorum. Resistant ecotypes showed a higher expression of $A t R b o h D$ and $F$ as well as an earlier accumulation of $\mathrm{NO}$ and $\mathrm{H}_{2} \mathrm{O}_{2}$ when compared to susceptible ecotypes during interaction with $\mathrm{S}$. sclerotiorum (Perchepied et al., 2010). Adding another layer of complexity to the interplay between NO and ROS, AtRbohD function was shown to be negatively regulated by NO-dependent S-nitrosylation during hypersensitive response (Yun et al., 2011).

The dependence of an oxidative burst on cell wall peroxidases was initially reported in carrot suspension cells (Bach et al., 1993). ROS formation dependent on an apoplastic peroxidase was later confirmed in other plants (bean, Arabidopsis, pepper, lettuce, cotton) (Bestwick et al., 1998; Bindschedler et al., 2006; Bolwell, 1999; Choi et al., 2007; Martinez et al., 1998). The relevance of apoplastic peroxidase was explored in A. thaliana expressing an antisense construct of the heme-containing cell-wall-bound class III peroxidase FBP1 of French bean. In such antisense plants the DPIinsensitive oxidative burst was decreased in response to cell wall preparations of Fusarium oxysporum. The antisense plants displayed enhanced susceptibility to a broad range of fungal and bacterial pathogens and showed a decrease in expression of mRNAs coding for peroxidase AtPCa (PRX33) and AtPCb (PRX34) (Bindschedler et al., 2006). When Arabidopsis tissue culture lines generated from FBP1 antisense plants are treated with ROS inhibitors (azide and DPI) about half of the MAMP-induced $\mathrm{H}_{2} \mathrm{O}_{2}$ can be accounted for by a peroxidase-generated reaction while the rest is likely to depend on NADPH oxidases and other sources. The expression of MAMPelicited genes including MYB51, CYP79B2, and CYP81F2 and the two cysteine-rich defence-related peptides PDF2.2 and PDF2.3 are decreased in the antisense cell lines (O'Brien et al., 2012b). The importance of peroxidase-mediated ROS formation was studied in Arabidopsis T-DNA insertion lines impaired in the expression of the PRX33 or PRX34 mRNAs. Mature leaves of such T-DNA knockdown lines respond to MAMPs (Flg22 and Elf26) with reduced ROS formation and callose deposition and a decreased induction of MAMP-activated genes. Finally, the PRX33 T-DNA knockdown line is more susceptible to $P$. syringae than wild-type plants, supporting a role for peroxidase-mediated oxidative burst in MAMP-mediated plant defence (Daudi et al., 2012).

In Arabidopsis, besides AtRboh the NADP-malic enzyme (NADPME) was recently shown to be associated with the formation of ROS and ROS-dependent defences. Inoculation with the hemibiotrophic fungal pathogen Colletotrichum higginsianum or with PAMPs (flagellin, chitin) increased the activity of NADP-ME and its transcript levels. In the loss-of-function T-DNA mutant nadpme2, ROS and the formation of callose are decreased in response to PAMPs and an increased susceptibility towards $C$. higginsianum was observed providing experimental support for a role of NADPME and associated ROS in plant defence (Voll et al., 2012).

Several necrotrophic pathogens produce oxalic acid (OA) during infection and OA can dampen the elicitor-triggered ROS production (Cessna et al., 2000). An interesting series of studies have tested the importance of $\mathrm{OA}$ as a pathogenicity factor and have yielded clues on the relevance of ROS during an interaction with necrotrophic fungal pathogens (for a summary see Walz et al., 2008a). Transgenic tomato expressing a wheat oxalate oxidase displayed oxalate oxidase activity and reduced symptoms after inoculation with $B$. cinerea (Walz et al., 2008b). Overexpression in tobacco of an oxalate decarboxylase from the basidiomycete Trametes versicolor that converts $\mathrm{OA}$ into $\mathrm{CO}_{2}$ and formate, leads to a strong ROS accumulation and delayed colonisation of S. sclerotiorum (Walz et al., 2008a). Arabidopsis overexpressing the oxalate decarboxylase gene of $T$. versicolor show a faster ROS accumulation after inoculation with $B$. cinerea and a decrease in lesion size compared to controls (L'Haridon et al., 2011). Thus, when necrotrophic pathogens are exposed to an oxidative burst during the initial phase of infection their invasion is weakened. Paradoxically, OA can also induce ROS formation and attending plant cell death at a later stage of the infection that benefits a necrotrophic pathogen. A study by Williams et al. (2011) nicely demonstrates how Sclerotinia mediates the redox environment in the host using real-time redox sensing by GFP, histological staining and reverse fungal genetics. At an early phase, Sclerotinia creates a reducing environment by secreting OA that prevents the ROS-induced localised defences. This allows an early establishment of the pathogen that at a later stage will exploit host ROS pathways and plant cell death to its own advantage and successful colonisation. A similar role for OA during the later phase of colonisation was highlighted in the interaction of tobacco with Moniliophthora perniciosa, the hemibiotrophic causal agent of witches broom disease (da Silva et al., 2011).

ROS are also part of the reactions that are activated when plants undergo priming for defences. Priming of the expression of genes associated with cell wall lignification and of the activity of ROS forming enzymes is induced during systemic resistance in cucumber against Colletotrichum orbiculare by acibenzolar-S-methyl treatments (Deepak et al., 2006). Treatments with the PAMP chitosan or with the fungus Plectosphaerella cucumerina both induce callose and ROS formation in Arabidopsis plants. When plants are pretreated with the priming agent $\beta$-aminobutyric acid (BABA), plants display resistance to the fungus. BABA treatment is also associated with a faster and stronger callose and ROS formation. The priming effect of BABA affects the homeostasis of ROS both by activating the expression and respectively the repression of ROS biosynthetic and scavenging enzymes. This highlights the importance of an oxidised cellular status for activation of defences in primed plants (Pastor et al., 2013). In grapevine suspension cells, BABA primes elicitation of ROS and expression of the RbohD gene. In leaves of grapevine, BABA primes for a stronger ROS production in response to the downy mildew agent Plasmopara viticola that correlated with an increased resistance to this pathogen. Primed ROS formation and BABA-induced resistance was blocked by DPI (an inhibitor of NADPH oxidoreductases) suggesting that NADPH oxidase-dependent ROS production is crucial to the effect of BABA in grapevine infected by $P$. viticola (Dubreuil-Maurizi et al., 2010).

\section{ROS and resistance to fungal pathogens of roots}

Although ROS synthesis and function in foliar plant diseases have been described extensively, little is known about the implica- 
tion of ROS in defence reactions of the root. The chitin-elicited production of ROS and of $\mathrm{H}_{2} \mathrm{O}_{2}$ in particular has been demonstrated in roots of M. truncatula and Arabidopsis (Kim et al., 2006; Nars et al., 2013; Plancot et al., 2013). Using an elicitor from Fusarium oxysporum, increased levels of superoxide and $\mathrm{H}_{2} \mathrm{O}_{2}$ were also detected in the border-like cells of Arabidopsis and flax roots (Plancot et al., 2013).

The impact of actively growing $F$. oxysporum on ROS levels was demonstrated when elevated amounts of ROS and nitric oxide were visualised in Arabidopsis roots following inoculation (Gupta et al., 2013). Similarly, the generation of $\mathrm{H}_{2} \mathrm{O}_{2}$ was detected in cotton roots after infection with Verticillium dahliae (Xie et al., 2013). In a study investigating $\mathrm{H}_{2} \mathrm{O}_{2}$ generation upon $V$. dahliae infection, $\mathrm{H}_{2} \mathrm{O}_{2}$ production in tomato plants carrying the Ve resistance gene preceded that observed in a susceptible variety (Gayoso et al., 2010). Transgenic cotton plants expressing a fungal endochitinase gene are more resistant towards Rhizoctonia solani and accumulated ROS faster than the wild type after inoculation with the pathogen (Kumar et al., 2009). These data demonstrate that root invasion by a pathogen is accompanied by increased ROS accumulation and suggest that ROS levels are associated to disease resistance.

Our understanding of the ROS-generating processes during root-pathogen interaction is still rudimentary. Bai et al. (2013) detected a reduced expression of an Rboh homolog from banana following inoculation with $F$. oxysporum in a resistant cultivar, whereas roots of a susceptible cultivar showed increased Rboh transcript levels (Bai et al., 2013). An independent transcriptional analysis of banana roots undergoing compatible interaction with F. oxysporum found the induction of an RbohD homolog (Park et al., 2012). When expression of the 10 AtRboh homologs was compared in F. oxysporum-inoculated Arabidopsis roots, AtRbohD revealed the most pronounced induction while AtRboh $A, B$ and $F$ were slightly increased. Interestingly, this study also demonstrates that an atrbohD insertion mutant is more resistant to $F$. oxysporum, while atrbohF plants develop more severe disease symptoms than the wild type (Zhu et al., 2013). Transcriptional analyses of $F$. oxysporum-inoculated banana and Arabidopsis plants also detected an upregulation of several peroxidase genes, but a direct link between peroxidase activity and disease development has yet to be established (Li et al., 2013; Zhu et al., 2013).

The family of germin-like proteins (GLP) have been associated with $\mathrm{H}_{2} \mathrm{O}_{2}$ accumulation in infected plants (Christensen et al., 2004; Schweizer et al., 1999). GLPs include enzymes with oxalate oxidase (OxO) or superoxide dismutase (SOD) activities leading to $\mathrm{H}_{2} \mathrm{O}_{2}$ production (Zimmermann et al., 2006). Expression of the $B v G L P-1$ gene of sugar beet in Arabidopsis increased the $\mathrm{H}_{2} \mathrm{O}_{2}$ content in the transgenic plants and conferred resistance to $\mathrm{V}$. longisporum and $R$. solani (Knecht et al., 2010). The authors of this study proposed that $\mathrm{H}_{2} \mathrm{O}_{2}$ produced by $B v G L P-1$ may function as a signal activating plant defence responses since the transgenic plants exhibited enhanced transcript levels of both the SA-dependent $P R-1$ and $P R-2$ genes and the JA/ET-dependent PR-3, PR-4 and PDF1.2 genes (Knecht et al., 2010). Catalase peroxidase is one of the most prominent upregulated proteins observed when $V$. longisporum senses xylem sap of rapeseed. Reducing the expression of these proteins in $V$. longisporum using RNAi-mediated gene silencing increased the sensitivity of the fungus to ROS and affected the performance of the fungus during the late phases of the disease (Singh et al., 2011). This provides an indirect evidence for the importance of ROS in the defence of rapeseed to $\mathrm{V}$. longisporum.

\section{Conclusions}

ROS are increasingly recognised as important molecules participating in various processes ranging from development to responses of plants to stress. This review focussed on the involvement of ROS in the interaction between plants and pathogenic fungi. Interestingly, ROS can act as developmental signals for the differentiation of infection structures in fungal pathogens. Besides, while ROS are known for their direct antimicrobial role against pathogens they are more likely cofactors in redox reactions playing various roles in plant defences. To this point one of the difficulties remains the localisation of the relevant ROS species, their levels and their dynamics in various tissues and at the cellular level. Our knowledge is limited by a suboptimal temporal and spatial resolution describing ROS kinetics during local and systemic responses. A major challenge in this field will be the development of methods that allow unambiguous detection and quantification of specific ROS. The parallel analysis of ROS in the apoplast as well as in different subcellular compartments will advance as novel technical developments become available. Another challenge is to fully understand how changing ROS levels translate into specific biological outcomes. Such knowledge will help to elucidate the connections among the diverse signalling elements employed by the cell.

\section{Acknowledgement}

The support of the Swiss National Science Foundation to JPM is gratefully acknowledged.

\section{References}

Agurla, S., Gayatri, G., Raghavendra, A.S., in press. Nitric oxide as a secondary messenger during stomatal closure as a part of plant immunity response against pathogens. Nitric Oxide, http://dx.doi.org/10.1016/j.niox.2014.07.004.

Almagro, L, Gómez Ros, L.V., Belchi-Navarro, S, Bru, R, Ros Barceló, A, Pedreño, M.A., 2009. Class III peroxidases in plant defence reactions. J. Exp. Bot. 60, 377390.

Apel, K., Hirt, H., 2004. Reactive oxygen species: metabolism, oxidative stress, and signal transduction. Annu. Rev. Plant Biol. 55, 373-399.

Asai, S., Ohta, K., Yoshioka, H., 2008. MAPK signaling regulates nitric oxide and NADPH oxidase-dependent oxidative bursts in Nicotiana benthamiana. Plant Cell 20, 1390-1406.

Asai, S., Yoshioka, H., 2009. Nitric oxide as a partner of reactive oxygen species participates in disease resistance to necrotrophic pathogen Botrytis cinerea in Nicotiana benthamiana. Mol. Plant Microbe Interact. 22, 619-629.

Asai, S., Mase, K., Yoshioka, H., 2010. Role of nitric oxide and reactive oxygen species in disease resistance to necrotrophic pathogens. Plant Signal. Behav. 5, 872 874.

Bach, M., Schnitzler, J.P., Seitz, H.U., 1993. Elicitor-induced changes in $\mathrm{Ca}^{2+}$ influx, $\mathrm{K}^{+}$ efflux, and 4-hydroxybenzoic acid synthesis in protoplasts of Daucus carota L. Plant Physiol. 103, 407-412.

Bacic, G., Mojovic, M., 2005. EPR Spin trapping of oxygen radicals in plants: a methodological overview. Ann. New York Acad. Sci. 1048, 230-243.

Bai, T.T., Xie, W.B., Zhou, P.P., Wu, Z.L., Xiao, W.C., Zhou, L., Sun, J., Ruan, X.L., Li, H.P. 2013. Transcriptome and expression profile analysis of highly resistant and susceptible banana roots challenged with Fusarium oxysporum f. sp. cubense tropical race 4. PLoS ONE 8, e73945.

Baker, C.J., Orlandi, E.W., 1995. Active oxygen in plant pathogenesis. Annu. Rev. Phytopathol. 33, 299-321.

Barna, B., Fodor, J., Harrach, B.D., Pogány, M., Király, Z., 2012. The Janus face of reactive oxygen species in resistance and susceptibility of plants to necrotrophic and biotrophic pathogens. Plant Physiol. Biochem. 59, 37-43.

Baxter, A., Mittler, R., Suzuki, N., 2013. ROS as key players in plant stress signalling. J. Exp. Bot. Bot. 65, 1229-1240.

Becana, M., Aparicio-Tejo, P., Irigoyen, J.J., Sanchez-Diaz, M., 1986. Some enzymes of hydrogen peroxide metabolism in leaves and root nodules of Medicago sativa Plant Physiol. 82, 1169-1171.

Bellin, D., Asai, S., Delledonne, M., Yoshioka, H., 2012. Nitric oxide as a mediator for defense responses. Mol. Plant Microbe Interact. 26, 271-277.

Bellincampi, D., Dipierro, N., Salvi, G., Cervone, F., De Lorenzo, G., 2000. Extracellular $\mathrm{H}_{2} \mathrm{O}_{2}$ induced by oligogalacturonides is not involved in the inhibition of the auxin-regulated rolb gene expression in tobacco leaf explants. Plant Physiol. $122,1379-1386$.

Beneloujaephajri, E., Costa, A., L'Haridon, F., Metraux, J.P., Binda, M., 2013. Production of reactive oxygen species and wound-induced resistance in Arabidopsis thaliana against Botrytis cinerea are preceded and depend on a burst of calcium. BMC Plant Biol. 13, 160.

Benikhlef, L., L'Haridon, F., Abou-Mansour, E., Serrano, M., Binda, M., Costa, A Lehmann, S., Metraux, J.P., 2013. Perception of soft mechanical stress in Arabidopsis leaves activates disease resistance. BMC Plant Biol. 13, 133. 
Bestwick, C.S., Brown, I.R., Mansfield, J.W., 1998. Localized changes in peroxidase activity accompany hydrogen peroxide generation during the development of a nonhost hypersensitive reaction in lettuce. Plant Physiol. 118, 1067-1078.

Bindschedler, L.V., Dewdney, J., Blee, K.A., Stone, J.M., Asai, T., Plotnikov, J., Denoux, C., Hayes, T., Gerrish, C., Davies, D.R., Ausubel, F.M., Bolwell, G.P., 2006. Peroxidase-dependent apoplastic oxidative burst in Arabidopsis required for pathogen resistance. Plant J. 47, 851-863.

Boller, T., Felix, G., 2009. A renaissance of elicitors: perception of microbeassociated molecular patterns and danger signals by pattern-recognition receptors. Annu. Rev. Plant Biol. 60, 379-406.

Bolwell, G.P., 1999. Role of active oxygen species and NO in plant defence responses. Curr. Opin. Plant Biol. 2, 287-294.

Boubakri, H., Wahab, M.A., Chong, J., Gertz, C., Gandoura, S., Mliki, A., Bertsch, C., Soustre-Gacougnolle, I., 2013. Methionine elicits $\mathrm{H}_{2} \mathrm{O}_{2}$ generation and defense gene expression in grapevine and reduces Plasmopara viticola infection. J. Plant Physiol. 170, 1561-1568.

Bulgakov, V.P., Gorpenchenko, T.Y., Veremeichik, G.N., Shkryl, Y.N., Tchernoded, G.K., Bulgakov, D.V., Aminin, D.L., Zhuravlev, Y.N., 2012. The Rolb gene suppresses reactive oxygen species in transformed plant cells through the sustained activation of antioxidant defense. Plant Physiol. 158, 1371-1381.

Cessna, S.G., Sears, V.E., Dickman, M.B., Low, P.S., 2000. Oxalic acid, a pathogenicity factor for Sclerotinia sclerotiorum, suppresses the oxidative burst of the host plant. Plant Cell 12, 2191-2200.

Chaouch, S., Queval, G., Noctor, G., 2012. AtRbohF is a crucial modulator of defenceassociated metabolism and a key actor in the interplay between intracellular oxidative stress and pathogenesis responses in Arabidopsis. Plant J. 69, 613627.

Choi, H.W., Kim, Y.J., Lee, S.C., Hong, J.K., Hwang, B.K., 2007. Hydrogen peroxide generation by the pepper extracellular peroxidase $\mathrm{CaPO}_{2}$ activates local and systemic cell death and defense response to bacterial pathogens. Plant Physiol. 145, 890-904.

Christensen, A.B., Thordal-Christensen, H., Zimmermann, G., Gjetting, T., Lyngkjær, M.F., Dudler, R., Schweizer, P., 2004. The germinlike protein GLP4 exhibits superoxide dismutase activity and is an important component of quantitative resistance in wheat and barley. Mol. Plant Microbe Interact. 17, 109-117.

da Silva, L.F., Dias, C.V., Cidade, L.C., Mendes, J.S., Pirovani, C.P., Alvim, F.C., Pereira, G.A.G., Aragao, F.J.L., Cascardo, J.C.M., Costa, M.G.C., 2011. Expression of an oxalate decarboxylase impairs the necrotic effect induced by NEP1-like protein (NLP) of Moniliophthora perniciosa in transgenic tobacco. Mol. Plant Microbe Interact. 24, 839-848.

Daudi, A., Cheng, Z., O’Brien, J.A., Mammarella, N., Khan, S., Ausubel, F.M., Bolwell, G.P., 2012. The apoplastic oxidative burst peroxidase in Arabidopsis is a major component of pattern-triggered immunity. Plant Cell 24, 275-287.

e Tullio, M.C., 2010. Antioxidants and redox regulation: changing notions in a changing world. Plant Physiol. Biochem. 48, 289-291.

Deepak, S.A., Ishii, H., Park, P., 2006. Acibenzolar-S-methyl primes cell wall strengthening genes and reactive oxygen species forming/scavenging enzymes in cucumber after fungal pathogen attack. Physiol. Mol. Plant Pathol. 69, 52-61.

Després, C., Chubak, C., Rochon, A., Clark, R., Bethune, T., Desveaux, D., Fobert, P.R., 2003. The Arabidopsis NPR1 disease resistance protein is a novel cofactor that confers redox regulation of DNA binding activity to the basic domain/Leucine zipper transcription factor TGA1. Plant Cell 15, 2181-2191.

Dickman, M.B., de Figueiredo, P., 2013. Death be not proud-Cell death control in plant fungal interactions. PLoS Pathog. 9, e1003542.

Doke, N., 1983. Involvement of superoxide anion generation in the hypersensitive response of potato-tuber tissues to infection with an incompatible race of Phytophthora infestans and to the hyphal wall components. Physiol. Plant Pathol. 23, 345-357.

Dubreuil-Maurizi, C., Trouvelot, S., Frettinger, P., Pugin, A., Wendehenne, D., Poinssot, B., 2010. $\beta$-Aminobutyric acid primes an NADPH oxidase-dependent reactive oxygen species production during grapevine-triggered immunity. Mol. Plant Microbe Interact. 23, 1012-1021.

Elstner, E.F., 1982. Oxygen activation and oxygen-toxicity. Annu. Rev. Plant Physiol. Plant Mol. Biol. 33, 73-96.

Fester, T., Hause, G., 2005. Accumulation of reactive oxygen species in arbuscular mycorrhizal roots. Mycorrhiza 15, 373-379.

Flors, C., Fryer, M.J., Waring, J., Reeder, B., Bechtold, U., Mullineaux, P.M., Nonell, S., Wilson, M.T., Baker, N.R., 2006. Imaging the production of singlet oxygen in vivo using a new fluorescent sensor, Singlet Oxygen Sensor Green. J. Exp. Bot. 57, 1725-1734.

Flury, P., Klauser, D., Schulze, B., Boller, T., Bartels, S., 2013. The anticipation of danger: microbe-associated molecular pattern perception enhances AtPeptriggered oxidative burst. Plant Physiol. 161, 2023-2035.

Foyer, C.H., Noctor, G., 2013. Redox signaling in plants. Antioxid. Redox Signal. 18, 2087-2090.

Freinbichler, W., Colivicchi, M., Stefanini, C., Bianchi, L., Ballini, C., Misini, B. Weinberger, P., Linert, W., Varešlija, D., Tipton, K., Della Corte, L., 2011. Highly reactive oxygen species: detection, formation, and possible functions. Cell. Mol. Life Sci. 68, 2067-2079.

Fu, Z.Q., Dong, X., 2013. Systemic acquired resistance: turning local infection into global defense. Annu. Rev. Plant Biol. 64, 839-863.

Galletti, R., Denoux, C., Gambetta, S., Dewdney, J., Ausubel, F.M., Lorenzo, G.D., Ferrari, S., 2008. The AtrbohD-mediated oxidative burst elicited by oligogalacturonides in Arabidopsis thaliana is dispensable for the activation of defense responses effective against Botrytis cinerea. Plant Physiol. 148, 16951706.

Garcion, C., Lamotte, O., Cacas, J.L., Métraux, J.P., 2014. Mechanisms of defence to pathogens: biochemistry and physiology. In: Walters, D., Newton, A., Lyon, G. (Eds.), Induced Resistance for Plant Defence: A Sustainable Approach to Crop Protection. Blackwell Press, Oxford, pp. 106-133 (Chapter 6), in press.

Gayoso, C., Pomar, F., Novo-Uzal, E., Merino, F., Martinez de Ilarduya, O., 2010. The Ve-mediated resistance response of the tomato to Verticillium dahliae involves $\mathrm{H}_{2} \mathrm{O}_{2}$, peroxidase and lignins and drives PAL gene expression. BMC Plant Biol. $10,232$.

Grosskinsky, D.K., Koffler, B.E., Roitsch, T., Maier, R., Zechmann, B., 2012. Compartment-specific antioxidative defense in Arabidopsis against virulent and avirulent Pseudomonas syringae. Phytopathology 102, 662-673.

Guo, M., Guo, W., Chen, Y., Dong, S., Zhang, X., Zhang, H., Song, W., Wang, W., Wang, Q. Lv, R. Zhang, Z., Wang, Y., Zheng, X. 2010. The basic leucine zipper transcription factor Moatf1 mediates oxidative stress responses and is necessary for full virulence of the rice blast fungus Magnaporthe oryzae. Mol. Plant Microbe Interact. 23, 1053-1068.

Gupta, S., Bhar, A., Chatterjee, M., Das, S., 2013. Fusarium oxysporum f.sp. ciceri race 1 induced redox state alterations are coupled to downstream defense signaling in root tissues of chickpea (Cicer arietinum L.). PLoS ONE 8, e73163.

Hardin, S.C., Larue, C.T., Oh, M.H., Jain, V., Huber, S.C., 2009. Coupling oxidative signals to protein phosphorylation via methionine oxidation in Arabidopsis. Biochem. J. 422, 305-312.

Heller, J., Meyer, A.J., Tudzynski, P., 2012. Redox-sensitive GFP2: use of the genetically encoded biosensor of the redox status in the filamentous fungus Botrytis cinerea. Mol. Plant Pathol. 13, 935-947.

Heller, J., Tudzynski, P., 2011. Reactive oxygen species in phytopathogenic fungi: signaling development, and disease. Annu. Rev. Phytopath. 49, 369-390.

Hideg, E., Barta, C., Kalai, T., Vass, I., Hideg, K., Asada, K., 2002. Detection of singlet oxygen and superoxide with fluorescent sensors in leaves under stress by photoinhibition or UV radiation. Plant Cell Physiol. 43, 1154-1164.

Hideg, E., Spetea, C., Vass, I., 1994. Singlet oxygen production in thylakoid membranes during photoinhibition as detected by EPR spectroscopy. Photosynth. Res. 39, 191-199.

Hideg, E., Spetea, C., Vass, I., 1995. Superoxide radicals are not the main promoters of acceptor-side-induced photoinhibitory damage in spinach thylakoids. Photosynth. Res. 46, 399-407.

Huang, K., Czymmek, K.J., Caplan, J.L., Sweigard, J.A., Donofrio, N.M., 2011. HYR1mediated detoxification of reactive oxygen species is required for full virulence in the rice blast fungus. PLoS Pathog. 7, e1001335.

Jabs, T., Dietrich, R.A., Dangl, J.L., 1996. Initiation of runaway cell death in an Arabidopsis mutant by extracellular superoxide. Science 273, 1853-1856.

Jubany-Mari, T., Alegre-Batlle, L., Jiang, K., Feldman, L.J., 2010. Use of a redoxsensing GFP (c-roGFP1) for real-time monitoring of cytosol redox status in Arabidopsis thaliana water-stressed plants. FEBS Lett. 584, 889-897.

Kawarazaki, T., Kimura, S., Iizuka, A., Hanamata, S., Nibori, H., Michikawa, M., Imai, A., Abe, M., Kaya, H., Kuchitsu, K., 2013. A low temperature-inducible protein AtSRC2 enhances the ROS-producing activity of NADPH oxidase AtRbohF. Biochim. Biophys. Acta - Mol. Cell Res. 1833, 2775-2780.

Kim, C., Meskauskiene, R., Zhang, S., Lee, K.P., Lakshmanan Ashok, M., Blajecka, K., Herrfurth, C., Feussner, I., Apel, K., 2012. Chloroplasts of Arabidopsis are the source and a primary target of a plant-specific programmed cell death signaling pathway. Plant Cell 24, 3026-3039.

Kim, S.Y., Sivaguru, M., Stacey, G., 2006. Extracellular ATP in plants. Visualization, localization, and analysis of physiological significance in growth and signaling. Plant Physiol. 142, 984-992.

Knecht, K., Seyffarth, M., Desel, C., Thurau, T., Sherameti, I., Lou, B., Oelmuller, R., Cai, D., 2010. Expression of BvGLP-1 encoding a germin-like protein from sugar beet in Arabidopsis thaliana leads to resistance against phytopathogenic fungi. Mol. Plant Microbe Interact. 23, 446-457.

Kobayashi, M., Yoshioka, M., Asai, S., Nomura, H., Kuchimura, K, Mori, H., Doke, N., Yoshioka, H., 2012. StCDPK5 confers resistance to late blight pathogen but increases susceptibility to early blight pathogen in potato via reactive oxygen species burst. New Phytol. 196, 223-237.

Kolla, V.A., Vavasseur, A., Raghavendra, A.S., 2007. Hydrogen peroxide production is an early event during bicarbonate induced stomatal closure in abaxial epidermis of Arabidopsis. Planta 225, 1421-1429.

Kumar, V., Parkhi, V., Kenerley, C.M., Rathore, K.S., 2009. Defense-related gene expression and enzyme activities in transgenic cotton plants expressing an endochitinase gene from Trichoderma virens in response to interaction with Rhizoctonia solani. Planta 230, 277-291.

Kunz, C., Vandelle, E., Rolland, S., Poinssot, B., Bruel, C., Cimerman, A., Zotti, C., Moreau, E., Vedel, R., Pugin, A., Boccara, M., 2006. Characterization of a new, nonpathogenic mutant of Botrytis cinerea with impaired plant colonization capacity. New Phytol. 170, 537-550.

L'Haridon, F., Besson-Bard, A., Binda, M., Serrano, M., Abou-Mansour, E., Balet, F., Schoonbeek, H.-J., Hess, S., Mir, R., Leon, J., Lamotte, O., Metraux, 2011. A permeable cuticle is associated with the release of reactive oxygen species and induction of innate immunity. PLoS Path, e1002148.

Laloi, C., Apel, K., Danon, A., 2004. Reactive oxygen signalling: the latest news. Curr. Opin. Plant Biol. 7, 323

Lehmann, M., Schwarzlander, M., Obata, T., Sirikantaramas, S., Burow, M., Olsen, C.E., Tohge, T., Fricker, M.D., Moller, B.L., Fernie, A.R., Sweetlove, L.J., Laxa, M., 2009. The metabolic response of Arabidopsis roots to oxidative stress is distinct 
from that of heterotrophic cells in culture and highlights a complex relationship between the levels of transcripts, metabolites, and flux. Mol. Plant 2, 390-406.

Lehotai, N., Petö, A., Bajkan, S., Erdei, L., Tari, I., Kolbert, Z., 2011. In vivo and in situ visualization of early physiological events induced by heavy metals in pea roo meristem. Acta Physiol. Plant. 33, 2199-2207.

Lherminier, J., Elmayan, T., Fromentin, J., Elaraqui, K.T., Vesa, S., Morel, J., Verrier, J.L., Cailleteau, B., Blein, J.P., Simon-Plas, F., 2009. NADPH oxidase-mediated reactive oxygen species production: subcellular localization and reassessment of its role in plant defense. Mol. Plant Microbe Interact. 22, 868-881.

Li, B., Xing, D., Zhang, L., 2007. Involvement of NADPH oxidase in sulfur dioxideinduced oxidative stress in plant cells. Photochem. Photobiol. Sci. 6, 628-634.

Li, C., Shao, J., Wang, Y., Li, W., Guo, D., Yan, B., Xia, Y., Peng, M., 2013. Analysis of banana transcriptome and global gene expression profiles in banana roots in response to infection by race 1 and tropical race 4 of Fusarium oxysporum f. sp. cubense. BMC Genomics 14, 851.

Liao, Y.-W.-K., Shi, K., Fu, L.-J., Zhang, S., Li, X., Dong, D.-K., Jiang, Y.-P., Zhou, Y.-H. Xia, X.-J., Liang, W.-S., Yu, J.Q., 2012. The reduction of reactive oxygen species formation by mitochondrial alternative respiration in tomato basal defense against TMV infection. Planta 235, 225-238.

Liu, X., Williams, C.E., Nemacheck, J.A., Wang, H., Subramanyam, S., Zheng, C., Chen, M.-S., 2010. Reactive oxygen species are involved in plant defense against a gall midge. Plant Physiol. 152, 985-999.

Ma, Y., Zhao, Y., Walker, R.K., Berkowitz, G.A., 2013. Molecular steps in the immune signaling pathway evoked by plant elicitor peptides: $\mathrm{Ca}^{2+}$-dependent protein kinases, nitric oxide, and reactive oxygen species are downstream from the early $\mathrm{Ca}^{2+}$ signal. Plant Physiol. 163, 1459-1471.

Mai, V.C., Bednarski, W., Borowiak-Sobkowiak, B., Wilkaniec, B., Samardakiewicz, S. Morkunas, I., 2013. Oxidative stress in pea seedling leaves in response to Acyrthosiphon pisum infestation. Phytochemistry 93, 49-62.

Malolepsza, U., Rozalska, S., 2005. Nitric oxide and hydrogen peroxide in tomato resistance: Nitric oxide modulates hydrogen peroxide level in 0 hydroxyethylorutin-induced resistance to Botrytis cinerea in tomato. Plant Physiol. Biochem. 43, 623-635.

Marino, D., Dunand, C., Puppo, A., Pauly, N., 2012. A burst of plant NADPH oxidases. Trends Plant Sci. 17, 9-15.

Martinez, C., Montillet, J.L., Bresson, E., Agnel, J.P., Dai, G.H., Daniel, J.F., Geiger, J.P., Nicole, M., 1998. Apoplastic peroxidase generates superoxide anions in cells of cotton cotyledons undergoing the hypersensitive reaction to Xanthomonas campestris pv. malvacearum race 18. Mol. Plant Microbe Interact. 11, 1038 1047.

Mehdy, M.C., 1994. Active oxygen species in plant defense against pathogens. Plant Physiol. 105, 467-472.

Mersmann, S., Bourdais, G., Rietz, S., Robatzek, S., 2010. Ethylene signaling regulates accumulation of the FLS2 receptor and is required for the oxidative burst contributing to plant immunity. Plant Physiol. 154, 391-400.

Messner, B., Boll, M., 1994. Cell-suspension cultures of spruce (Picea abies) Inactivation of extracellular enzymes by fungal elicitor-induced transient release of hydrogen peroxide (oxidative burst). Plant Cell Tissue Organ Cult. 39, 69-78.

Miller, G., Shulaev, V., Mittler, R., 2008. Reactive oxygen signaling and abiotic stress. Physiol. Planta 133, 481-489.

Mittler, R., 2002. Oxidative stress, antioxidants and stress tolerance. Trends Plant Sci. 7, 405.

Mittler, R., Vanderauwera, S., Suzuki, N., Miller, G., Tognetti, V.B., Vandepoele, K, Gollery, M., Shulaev, V., Van Breusegem, F., 2011. ROS signaling: the new wave? Trends Plant Sci. 16, 300-309.

Molina, L., Kahmann, R., 2007. An Ustilago maydis gene involved in $\mathrm{H}_{2} \mathrm{O}_{2}$ detoxification is required for virulence. Plant Cell 19, 2293-2309.

Nars, A., Rey, T., Lafitte, C., Vergnes, S., Amatya, S., Jacquet, C., Dumas, B. Thibaudeau, C., Heux, L., Bottin, A., Fliegmann, J., 2013. An experimental system to study responses of Medicago truncatula roots to chitin oligomers of high degree of polymerization and other microbial elicitors. Plant Cell Rep. 32 489-502.

Nauseef, W.M., 2014. Detection of superoxide anion and hydrogen peroxide production by cellular NADPH oxidases. Biochim. Biophys. Acta - Genera Subjects 1840, 757-767.

O'Brien, J., Daudi, A., Butt, V., Paul Bolwell, G., 2012a. Reactive oxygen species and their role in plant defence and cell wall metabolism. Planta 236, 765-779.

O’Brien, J.A., Daudi, A., Finch, P., Butt, V.S., Whitelegge, J.P., Souda, P., Ausubel, F.M., Bolwell, G.P., 2012b. A peroxidase-dependent apoplastic oxidative burst in cultured Arabidopsis cells functions in MAMP-elicited defense. Plant Physiol. 158, 2013-2027.

Oger, E., Marino, D., Guigonis, J.-M., Pauly, N., Puppo, A., 2012. Sulfenylated proteins in the Medicago truncatula-Sinorhizobium meliloti symbiosis. J. Proteom. 75, 4102-4113.

Park, C.-H., Chen, S., Shirsekar, G., Zhou, B., Khang, C.H., Songkumarn, P., Afzal, A.J., Ning, Y., Wang, R., Bellizzi, M., Valent, B., Wang, G.-L., 2012. The Magnaporthe oryzae effector AvrPiz-t targets the RING E3 ubiquitin ligase APIP6 to suppress pathogen-associated molecular pattern-triggered immunity in rice. Plant Cel $24,4748-4762$

Pastor, V. Luna, E. Ton, J., Cerezo, M., García-Agustín, P., Flors, V., 2013. Fine tuning of reactive oxygen species homeostasis regulates primed immune responses in Arabidopsis. Mol. Plant Microbe Interact. 26, 1334-1344.

Peleg-Grossman, S., Melamed-Book, N., Levine, A., 2012. ROS production during symbiotic infection suppresses pathogenesis-related gene expression. Plan Signal. Behav. 7, 409-415.
Pena, L.B., Barcia, R.A., Azpilicueta, C.E., Méndez, A.A.E., Gallego, S.M., 2012. Oxidative post translational modifications of proteins related to cell cycle are involved in cadmium toxicity in wheat seedlings. Plant Sci. 196, 1-7.

Perchepied, L., Balague, C., Riou, C., Claudel-Renard, C., Riviere, N., Grezes-Besset, B. Roby, D., 2010. Nitric oxide participates in the complex interplay of defenserelated signaling pathways controlling disease resistance to Sclerotinia sclerotiorum in Arabidopsis thaliana. Mol. Plant Microbe Interact. 23, 846-860.

Pető, A., Lehotai, N., Feigl, G., Tugyi, N., Ördög, A., Gémes, K., Tari, I., Erdei, L., Kolbert Z., 2013. Nitric oxide contributes to copper tolerance by influencing ROS metabolism in Arabidopsis. Plant Cell Rep. 32, 1913-1923.

Plancot, B., Santaella, C., Jaber, R., Kiefer-Meyer, M.C., Follet-Gueye, M.-L., Leprince, J.R.M., Gattin, I., Souc, C.L., Driouich, A., Vicre-Gibouin, M., 2013. Deciphering the responses of root border-like cells of Arabidopsis and flax to pathogen-derived elicitors. Plant Physiol. 163, 1584-1597.

Rasul, S., Dubreuil-Maurizi, C., Lamotte, O., Koen, E., Poinssot, B., Alcaraz, G. Wendehenne, D., Jeandroz, S., 2012. Nitric oxide production mediates oligogalacturonide-triggered immunity and resistance to Botrytis cinerea in Arabidopsis thaliana. Plant Cell Environ. 35, 1483-1499.

Rojas, C.M., Senthil-Kumar, M., Wang, K., Ryu, C.-M., Kaundal, A., Mysore, K.S., 2012. Glycolate oxidase modulates reactive oxygen species-mediated signal transduction during nonhost resistance in Nicotiana benthamiana and Arabidopsis. Plant Cell 24, 336-352.

Rosenwasser, S., Rot, I., Sollner, E., Meyer, A.J., Smith, Y., Leviatan, N., Fluhr, R., Friedman, H., 2011. Organelles contribute differentially to reactive oxygen species-related events during extended darkness. Plant Phys. 156, 185-201.

Samalova, M., Meyer, A.J., Gurr, S.J., Fricker, M.D., 2014. Robust anti-oxidant defences in the rice blast fungus Magnaporthe oryzae confer tolerance to the host oxidative burst. New Phytol. 201, 556-573.

Scheler, C., Durner, J., Astier, J., 2013. Nitric oxide and reactive oxygen species in plant biotic interactions. Curr. Opin. Plant Biol. 16, 534-539.

Schweizer, P., Christoffel, A., Dudler, R., 1999. Transient expression of members of the germin-like gene family in epidermal cells of wheat confers disease resistance. Plant J. 20, 540-552.

Shetty, N.P., Jorgensen, H.J.L., Jensen, J.D., Collinge, D.B., Shetty, H.S., 2008. Roles of reactive oxygen species in interactions between plants and pathogens. Eur. J. Plant Pathol. 121, 267-280.

Shin, R., Schachtman, D.P., 2004. Hydrogen peroxide mediates plant root cell response to nutrient deprivation. Proc. Natl. Acad. Sci. U.S.A. 101, $8827-$ 8832

Simon, U.K., Polanschütz, L.M., Koffler, B.E., Zechmann, B., 2013. High resolution imaging of temporal and spatial changes of subcellular ascorbate, glutathione and $\mathrm{H}_{2} \mathrm{O}_{2}$ distribution during Botrytis cinerea infection in Arabidopsis. PLoS ONE 8, e65811.

Singh, S., Braus-Stromeyer, S.A., Timpner, C., Valerius, O., von Tiedemann, A Karlovsky, P., Druebert, C., Polle, A., Braus, G.H., 2011. The plant host Brassica napus induces in the pathogen Verticillium longisporum the expression of functional catalase peroxidase which is required for the late phase of disease. Mol. Plant Microbe Interact. 25, 569-581.

Sutherland, M.W., 1991. The generation of oxygen radicals during host plantresponses to infection. Physiol. Mol. Plant Pathol. 39, 79-93.

Suzuki, N., Miller, G., Morales, J., Shulaev, V., Torres, M.A., Mittler, R., 2011 Respiratory burst oxidases: the engines of ROS signaling. Curr. Opin. Plant Biol. 14, 691-699.

Swanson, S., Gilroy, S., 2010. ROS in plant development. Physiol. Plant 138, 384 392.

Tada, Y., Mori, T., Shinogi, T., Yao, N., Takahashi, S., Betsuyaku, S., Sakamoto, M., Park, P., Nakayashiki, H., Tosa, Y., Mayama, S., 2004. Nitric oxide and reactive oxygen species do not elicit hypersensitive cell death but induce apoptosis in the adjacent cells during the defense response of oat. Mol. Plant Microbe Interact. $17,245-253$

Tada, Y., Spoel, S.H., Pajerowska-Mukhtar, K., Mou, Z., Song, J., Wang, C., Zuo, J., Dong, X., 2008. Plant immunity requires conformational changes of NPR1 via Snitrosylation and thioredoxins. Science 321, 952-956.

Thordal-Christensen, H., Zhang, Z., Wei, Y., Collinge, D.B., 1997. Subcellular localization of $\mathrm{H}_{2} \mathrm{O}_{2}$ in plants. $\mathrm{H}_{2} \mathrm{O}_{2}$ accumulation in papillae and hypersensitive response during the barley-powdery mildew interaction. Plant J. 11, 1187-1194.

Tian, S., Qin, G., Li, B., 2013. Reactive oxygen species involved in regulating fruit senescence and fungal pathogenicity. Plant Mol. Biol. 82, 593-602.

Torres, M.A., 2010. ROS in biotic interactions. Physiol. Plant 138, 414-429.

Torres, M.A., Dangl, J.L., Jones, J.D.G., 2002. Arabidopsis gp91phox homologues AtrbohD and AtrbohF are required for accumulation of reactive oxygen intermediates in the plant defense response. Proc. Natl. Acad. Sci. U.S.A. 99, 517-522.

Torres, M.A., Jones, J.D., Dangl, J.L., 2006. Reactive oxygen species signaling in response to pathogens. Plant Physiol. 141, 373-378.

Torres, M.A., Jones, J.D.G., Dangl, J.L., 2005. Pathogen-induced, NADPH oxidasederived reactive oxygen intermediates suppress spread of cell death in Arabidopsis thaliana. Nat. Genet. 37, 1130.

Torres, M.A., Morales, J., Sánchez-Rodríguez, C., Molina, A., Dangl, J.L., 2013. Functional interplay between Arabidopsis NADPH oxidases and heterotrimeric G protein. Mol. Plant Microbe Interact. 26, 686-694.

Triantaphylides, C., Krischke, M., Hoeberichts, F.A., Ksas, B., Gresser, G., Havaux, M., Van Breusegem, F., Mueller, M.J., 2008. Singlet oxygen is the major reactive oxygen species involved in photooxidative damage to plants. Plant Physiol. 148 , 960-968. 
Voll, L.M., Zell, M.B., Engelsdorf, T., Saur, A., Wheeler, M.G., Drincovich, M.E., Weber, A.P.M., Maurino, V.G., 2012. Loss of cytosolic NADP-malic enzyme 2 in Arabidopsis thaliana is associated with enhanced susceptibility to Colletotrichum higginsianum. New Phytol. 195, 189-202.

von Tiedemann, A., 1997. Evidence for a primary role of active oxygen species in induction of host cell death during infection of bean leaves with Botrytis cinerea. Physiol. Mol. Plant Pathol. 50, 151-166.

van Doorn, W.G., Beers, E.P., Dangl, J.L., Franklin-Tong, V.E., Gallois, P., HaraNishimura, I., Jones, A.M., Kawai-Yamada, M., Lam, E., Mundy, J., Mur, L.A., Petersen, M., Smertenko, A., Taliansky, M., Van Breusegem, F., Wolpert, T. Woltering, E., Zhivotovsky, B., Bozhkov, P.V., 2011. Morphological classification of plant cell deaths. Cell Death Differ. 18, 1241-1246.

Walz, A., Zingen-Sell, I., Theisen, S., Kortekamp, A., 2008a. Reactive oxygen intermediates and oxalic acid in the pathogenesis of the necrotrophic fungus Sclerotinia sclerotiorum. Eur. J. Plant Pathol. 120, 317-330.

Walz, A., Zingen-Sell, I., Loeffler, M., Sauer, M., 2008b. Expression of an oxalate oxidase gene in tomato and severity of disease caused by Botrytis cinerea and Sclerotinia sclerotiorum. Plant Pathol. 57, 453-458.

Wang, J., Higgins, V.J., 2006. Nitric oxide has a regulatory effect in the germination of conidia of Colletotrichum coccodes. Fungal Genet. Biol. 42, 284-292.

Wang, Y., Lin, A., Loake, G.J., Chu, C., 2013. $\mathrm{H}_{2} \mathrm{O}_{2}$-induced leaf cell death and the crosstalk of reactive nitric/oxygen species. J. Integr. Plant Biol. 55, 202-208.

Wen, F., Xing, D., Zhang, L., 2008. Hydrogen peroxide is involved in high blue lightinduced chloroplast avoidance movements in Arabidopsis. J. Exp. Bot. 59, 2891 2901.

Williams, B., Kabbage, M., Kim, H.-J., Britt, R., Dickman, M.B., 2011. Tipping the balance: Sclerotinia sclerotiorum secreted oxalic acid suppresses host defenses by manipulating the host redox environment. PLoS Pathog. 7, e1002107.

Williams, B., Verchot, J. Dickman, M.B. 2014. When supply does not meet demandER stress and plant programmed cell death. Front. Plant Sci. 5, 211. http:// dx.doi.org/10.3389/fpls.2014.00211.

Winterbourn, C.C., 2014. The challenges of using fluorescent probes to detect and quantify specific reactive oxygen species in living cells. Biochim. Biophys. Acta Gen. Subjects 1840, 730-738.

$($ Wrzaczek, M., Brosche, M., Kangasjarvi, J., 2013. ROS signaling loops - production, perception, regulation. Curr. Opin. Plant Biol. 16, 575-582.
Xia, X.-J., Wang, Y.-J., Zhou, Y.-H., Tao, Y., Mao, W.-H., Shi, K., Asami, T., Chen, Z., Yu, J.-Q., 2009. Reactive oxygen species are involved in brassinosteroid-induced stress tolerance in cucumber. Plant Physiol. 150, 801-814.

Xie, C.J., Wang, C.Y., Wang, X.K., Yang, X.Y., 2013. Proteomics-based analysis reveals that Verticillium dahliae toxin induces cell death by modifying the synthesis of host proteins. J. Gen. Plant Pathol. 79, 335-345.

Ye, W., Hossain, M.A., Munemasa, S., Nakamura, Y., Mori, I.C., Murata, Y., 2013. Endogenous abscisic acid is involved in methyl jasmonate-induced reactive oxygen species and nitric oxide production but not in cytosolic alkalization in Arabidopsis guard cells. J. Plant Physiol. 170, 1212-1215.

Yoda, H., Fujimura, K., Takahashi, H., Munemura, I., Uchimiya, H., Sano, H., 2009. Polyamines as a common source of hydrogen peroxide in host- and nonhost hypersensitive response during pathogen infection. Plant Mol. Biol. 70, 103-112.

Yokawa, K., Kagenishi, T., Kawano, T., Mancuso, S., Baluska, F., 2011. Illumination of Arabidopsis roots induces immediate burst of ROS production. Plant Signal. Behav. 6, 1460-1464.

Yoshioka, H., Numata, N., Nakajima, K., Katou, S., Kawakita, K., Rowland, O., Jones, J.D.G., Doke, N., 2003. Nicotiana benthamiana gp91 phox homologs NbrbohA and NbrbohB participate in $\mathrm{H}_{2} \mathrm{O}_{2}$ accumulation and resistance to Phytophthora infestans. Plant Cell 15, 706-718.

Yun, B.W., Feechan, A., Yin, M., Saidi, N.B., Le Bihan, T., Yu, M., Moore, J.W., Kang, J.G., Kwon, E., Spoel, S.H., Pallas, J.A., Loake, G.J., 2011. S-nitrosylation of NADPH oxidase regulates cell death in plant immunity. Nature 478, 264-268.

Zhang, L., Oh, Y., Li, H., Baldwin, I.T., Galis, I., 2012. Alternative oxidase in resistance to biotic stresses: Nicotiana attenuata AOX contributes to resistance to a pathogen and a piercing-sucking insect but not Manduca sexta larvae. Plant Physiol. 160, 1453-1467.

Zhu, Q.-H., Stephen, S., Kazan, K., Jin, G., Fan, L., Taylor, J., Dennis, E.S., Helliwell, C.A., Wang, M.-B., 2013. Characterization of the defense transcriptome responsive to Fusarium oxysporum infection in Arabidopsis using RNA-seq. Gene 512, 259266.

Zimmermann, G., Bäumlein, H., Mock, H.-P., Himmelbach, A., Schweizer, P., 2006. The multigene family encoding germin-like proteins of barley. Regulation and function in basal host resistance. Plant Physiol. 142, 181-192.

Zulfugarov, I.S., Tovuu, A., Kim, J.H., Lee, C.H., 2011. Detection of reactive oxygen species in higher plants. J. Plant Biol. 54, 351-357. 